\title{
養成校と実習指導者が協同で行う ルーブリック検証の試み
}

一内容分析を用いて使用者の感想の分析から課題と改善策を明らかにする—

\author{
Physical Therapy School and Clinical Training Facilities Cooperate \\ in Verifying Rubric: \\ Analysis of User's Feedbacks by Content Analysis to Clarify Tasks and Improvements
}

山下 喬之 ${ }^{1,2)}$ 四元 祐子 $^{3)}$ 松野下 $\quad$ 信三 ${ }^{3)}$ 長津 秀文 ${ }^{1)}$

TAKAYUKi YAMASHITA, RPT ${ }^{1,2)}$, Yuko YOTSUMOTO, HSM, OTR ${ }^{3)}$, Shinzo MATSUNOSHITA, OTR ${ }^{3)}$, HiDEFUMI NAGATSU, RPT ${ }^{1)}$

1) Department of Physical Therapy, Kagoshima Medical Professional College: 5417-1 Aza Utoguchi, Hirakawa-cho, Kagoshima-shi, Kagoshima 891-0133, Japan TEL+81 99-261-6161 E-mail:pt.yamashita@harada-gakuen.ac.jp

${ }^{2)}$ Department of Education, Graduate School of Kagoshima University

3) Department of Occupational Therapy, Kagoshima Medical Professional College

Rigakuryoho Kagaku 33(4): 675-682, 2018. Submitted Feb. 9, 2018. Accepted Apr. 1, 2018.

\begin{abstract}
Purpose] The present study was undertaken in order to obtain objective knowledge for revising rubric style. [Subjects and Methods] In the study, samples from 189 clinical training facilities were gathered. The questionnaire reply form used in this part of this research was free descriptions about feedbacks on using rubric, and the replies were subjected to content analysis. [Results] Fifty-four context units and 98 record units were extracted from the feedbacks. From the results, we were able to form 14 new sub categories and four more categories in rubric style. [Conclusion] The results of the content analysis explain that the feedbacks showed rubric's advantages, issues, improvement points, and future possibilities. The results of this study indicate that rubric can be a proper performance evaluation method. This study will be of value in the field of developing and revising very practical rubrics for authors.
\end{abstract}

Key words: rubric, clinical education, performance evaluation method

要旨 :〔目的〕ルーブリックを使用した実習指導者の感想を内容分析を用いて検証し, 様式改訂の際に必要となる客 観的な知見を得ることを目的とする。〔対象と方法〕臨床実習指導者 189 名を対象に，ルーブリックを使用した感想 を問う質問紙への回答を依頼し，自由記述欄に記述された内容を対象として，内容分析を行った。〔結果〕集約した 結果より，54の文脈単位と，98 の記録単位が抽出され，14のサブ・カテゴリから，さらに4つのカテゴリが形成さ れた。〔結語〕内容分析の結果から, ルーブリックの利点, 課題, 具体的な要改善箇所, 今後の可能性に関する知見 を得ることができた，本研究の結果は，今後実用性の高いルーブリックへと改訂を行う際の有益な根拠の一つとなる と考えている.

キーワード : ルーブリック, 臨床実習成績, 理学療法士教育

1) 学校法人原田学園＼cjkstart鹿児島医療技術専門学校＼cjkstart理学療法学科：鹿児島県鹿児島市平川町字宇都口5417-1 ( ₹ 891-0133) TEL 099-261-6161

2) 国立大学法人 鹿児島大学大学院 教育学研究科 教育実践総合専攻

3) 学校法人原田学園 鹿児島医療技術専門学校 作業療法学科 


\section{I.はじめに}

ルーブリックとは, ある課題についてできるように なってもらいたい特定の事柄を配置するための道具 1) のことで, パフォーマンス評価の観点から評価基準や到 達度が具体的な表現で可視化できる教育評価ツールとさ れている2．ルーブリックは，様々な教育分野に执いて 広く普及し, 医歯薬系の大学に扔ける臨地実習の評価へ の活用実践 3)をはじめ, 看護師養成課程やリハビリテー ション関連職種の養成課程に扮いてもその注目度は高 い. 特に近年では, 学内教育や臨床実習教育（以下，実 習教育）それぞれの分野に扔いて、ルーブリックの活用 した教育実践に関連する報告も数多くなっている ${ }^{4-6) . ~}$ また，何らかの教育実践にルーブリックを導入している 機関は, 学習の成果に係る評価やそれに関する基準の明 示化に関する法令の整備7)などの影響で, 教育目標や 成績評価基準の明確化に努めることが一般的となり, ルーブリックの公開にも積極的である.

理学療法士養成課程に扔ける実習教育は, 理学療法学 生（以下, 学生) が, 理学療法士としての基本的技能を 全般的にわたって養うために, 患者に対する理学療法の 過程を経験することで知識・技術を深め, 統合すること を目的に行う ${ }^{8)}$. しかし, その成績評価の特徵は指導者 個人の判断にゆだねられてしまうことが多いとされ，個 別教育であるが故の客観性や公平性の確保の困難さ9) や，合否判定に偏る総括的評価に重きが置かれ，学生を 形成的に評価するには不十分な状態である10) と言われ ている。 これらは，根拠に欠ける学生評価といった実習 教育に打ける「課題」として取り上げられることが多い. また，金山ら ${ }^{11)}$ は「養成校と実習指導者の間に, 教育 評価に対する意識に大きな差を生むことは, 実習教育を 通して学生の能力を育むための教育活動中に相互理解を 図ることが困難となる」と実習教育に扔ける教育評価の 課題を指摘している。筆者らも同様に, 実習成績評価の 客観性や公平性に関する課題や，養成校と実習施設との 教育連携の不十分な在り方に対しては, 実習教育全体の 質の低下を招くことになりかねない重要な課題として捉 えている.

また，近年では，よりよい実習教育が行われる指導体 制を目指すために，実習指導者自身や実習施設が教育的 視点を踏まえて指導方法を学ぶ重要性 ${ }^{12)}$ や, 実習指導 者と養成校との連携強化 ${ }^{13)}$ を推奨する提言が数多くな され，養成校と実習施設が独立してのぞむ教育的取り組 みのみならず，実習指導者の意見を取り入れたかたちで の学内教育と実習教育を結ぶ必要性が見直されるように なってきている.

本校では，これまでに述べた臨床実習に扔ける教育評 価の課題に加え, 養成校に扔ける養成形態自体や実習形 態の違い, 社会的ニーズの多様化などの理学療法士養成
課程自体の多様化した背景 14-16) が生んだ複雑な教育の 風土を，パフォーマンス評価の概念を取り入れた教育評 価の観点から課題の解決の可能性を見出し，ルーブリッ クを導入した。運用中のルーブリック ${ }^{17)}$ は, 理学療法 士教育ガイドライン 1 版 ${ }^{18)}$ と臨床実習教育マニュアル 第 5 版 ${ }^{19)}$ に基づき開発され，15 の評価項目を 4 段階の 尺度で評定し，評価基準を記すための記述語が書かれた 枠の余白には, 評価項目に関する指導内容を自由に記述 できるように余白が確保されている。ルーブリックの開 発は, 教授者固有の教育方法や対象学生の多様さなどか ら，それらのニーズに適合させた独自の作成が好ましく， 加えてその作成には関係者を加えて実施することが有益 であるとされている ${ }^{20)}$. そのため, 養成校教員 16 名に 加え, 本校の実習教育に理解を示している実習指導者 20 名（施設数 12 件）に依頼した試験運用の結果と, それ らに対する意見を合わせた多者間協議のもとに行った。 現在, 14 力月の開発期間と 3 年間の運用期間を経て, 実 習成績評価に㧍けるルーブリックの実用性を立証するた めに, 様式の信頼性と妥当性の検証を行う段階にある.

今回の研究では, 協同で開発したルーブリックを成績 評価様式として使用した実習指導者にその使用感を記述 してもらい，それらを養成校が質的な手法を用いて検証 する取り組みが教育連携の一環となることに意義を見出 している.そして，分析の結果として得られた知見から， 様式の構成から基準の内容, 運用の方法までを含め, 臨 床実習の成績評価様式として妥当に構成されているかを 問い直し，今後の改訂に役立てることを目的とする。

\section{II. 対象と方法}

1. 対象

調査の対象者は, 平成 28 年 3 月に開催された, 臨床 実習指導者会議（以下，指導者会議）に出席した実習指 導者 189 名 (平均臨床経験年数 11 年, 標準偏差 5.6 年) で, 参加者の所属内訳は, 鹿児島県 138 名, 宮崎県 26 名, 熊本県 14 名, 佐賀県 1 名, 長崎県 4 名, 大分県 3 名, 沖縄県 2 名, 静岡県 1 名であった. 指導者会議への参加 資格は特に規定していないが, 臨床実習施設（以下，実 習施設）の理学療法士責任者や実習教育担当責任者がそ の大半を占める. 本研究は, 鹿児島医療技術専門学校倫 理審査委員会の承認を得たものである（倫理審査番号： 17020).

\section{2. 方法}

本学科の指定する実習施設は全て学外の機関で, その 総数は, 10 県に 240 施設（平成 29 年度現在）を超え， 養成校がルーブリックを使用した全ての実習指導者を対 象に，それぞれの感じた使用感や意見の全てを聴取する ことには困難が伴う。したがって, 指導者会議参加者を 
対象に質問紙への回答を依頼する形式の調査方法を選定 した，質問紙は，A4 サイズ 1 枚の様式に 9 項目の設問 と自由記述欄で構成し, 設問の内容は, ルーブリック作 成時における留意点 ${ }^{1)}$ と, 養成校がルーブリックの評 価項目と各種基準の開発を行う際に留意した開発の要 点 17) を基準に考案した（表 1)。回答直前には対象者向 けに, ルーブリック評価の概要の再確認と, 回答を誘導 することとならない配慮を行う目的で，ルーブリックを 導入した趣旨や使用方法の再確認と, 実際に指導者の記 入した様式の一部を紹介するなどの具体的な実用実積の 報告を中心としたプレゼンテーションに加え, 今回の調 査の趣旨と回答方法の説明までを行った。質問紙はあら かじめ指導者会議前に実習指導者の座席の机上に配布し ておき, 調査の趣旨に同意した者のみ提出するという形 式をとった。回答には，各設問の問いに対し，そう思う (4 点), どちらかといえばそう思う（3 点）, どちらか といえばそう思わない（2 点），そう思わない（1 点）の 4 段階の判定と, 使用感の自由記述で, 20 分間を確保 した.

本研究における分析では, 実習指導者が自由記述欄に 記述した内容を中心に取り扱い, 検証方法は, 言語的に 記述されたものを体系的に定量化し, 数量的にデータ化 するという特徵を持つ Berelsonの内容分析の手法 21)を 用いた。

分析は，はじめに研究の目的である問い「ルーブリッ クの使用者となる実習指導者は, 新たに導入した様式を 使用してどう感じたか.」に対する回答文「ルーブリッ クの使用者となる実習指導者は, 新たに導入した様式を
使用して○○○と感じた.」を設定し，自由記載欄に実 習指導者の記述した内容全体を一文脈単位として，空欄 ○○にあてはまる記述部分を記録単位として抽出し た。次に, 記録単位から, 内容や意味が類似したり一致 したりする記録単位を探し，それらをサブ・カテゴリ化 し，さらにサブ・カテゴリに共通する内容と意味を導き 出し, カテゴリの内容を忠実に反映した表現を用いた命 名でカテゴリ化を行った。この際は, 同一記録単位群の 意味内容の類似性によって分析を進め, 常に分析過程全 体を視野に入れておく必要があるため, 全ての記録単位 を並べた一覧を模造紙で作成し, 紙面上における分類作 業を行い, 記録単位同士の関連性を外化させながら分析 を進めた。

記録単位の出現率（\%）は分母を全ての記録単位数, 分子をそれぞれのサブ・カテゴリとカテゴリに分類した 記録単位数として割合を算出した。また，分類の信頼性 の確保には, 研究の目的に沿った記録単位が抽出されて いるかを研究者間で協議することと，ルーブリックを用 いた実習成績評価の趣旨理解がなされているが, 直接的 に分類作業に携わらなかった第三者の理学療法学科管理 職教員（臨床経験 16 年, 教職員経験 6 年), 作業療法 学科管理職教員（臨床経験 7 年, 教職員経験 16 年) の 2 名に独立したカテゴリ化を依頼した。 抽出されたカテ ゴリの信頼性検証には，舟島らの推奨する Scott.W.Aの 式 22) を用いてカテゴリ判断の一致率を算出し，信頼性 確保の基準は, 先行研究等を参考に一致率 $70 \%$ 以上 ${ }^{22)}$ を信頼性が確保されていると判断した。

表 1 質問紙の様式と設問

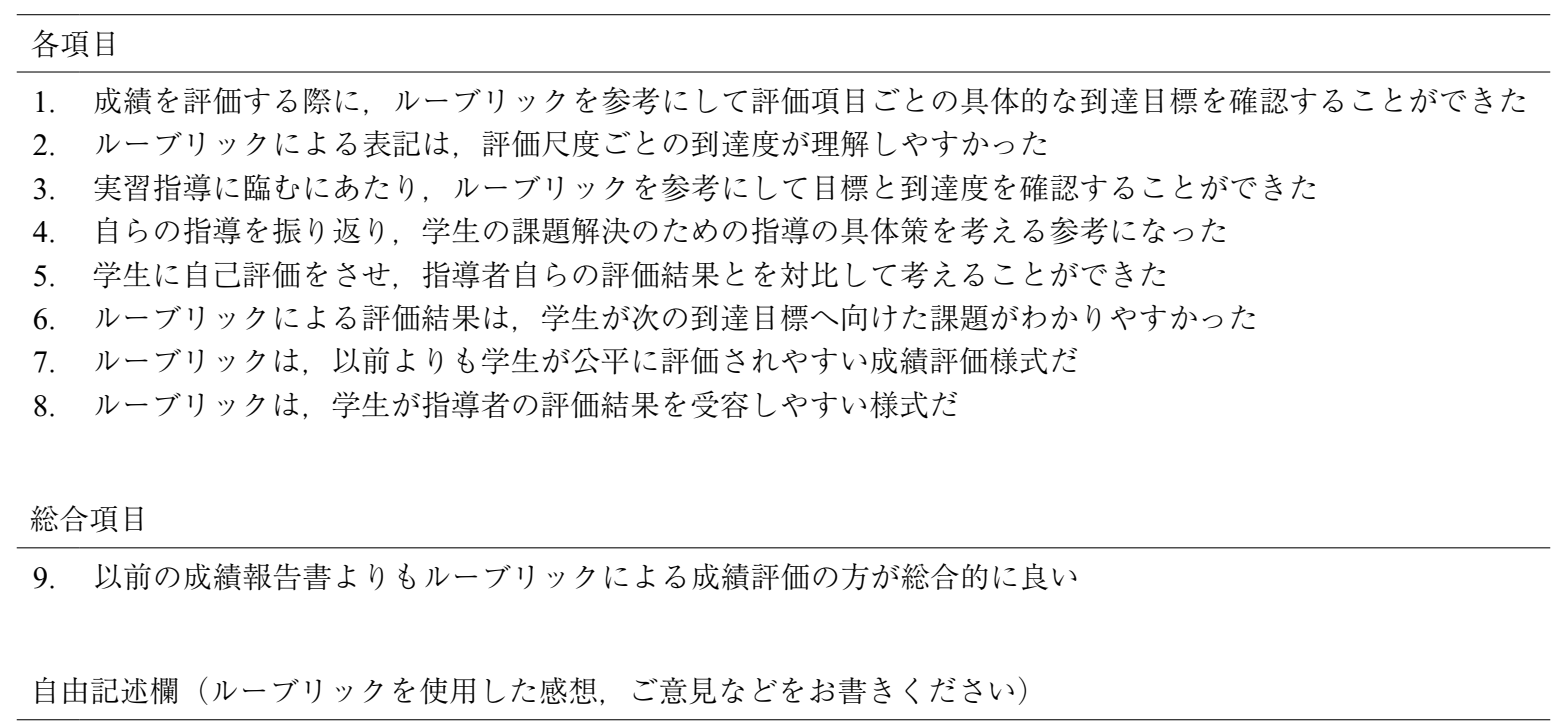




\section{III. 結 果}

配布した質問紙 189 部のうち，ルーブリックの使用 経験があり，同意が得られて回収できた質問紙は 158 部で, 自由記述がない, 今回の内容分析に適さない回答 をしたなどの 2 部を除き, $82.5 \%$ の有効回答率であった. 自由記述欄の記述内容は, 延べ 54 単位の文脈単位から 110 単位の記録単位が抽出され, 意味内容が類似しない もの 12 単位を除外した 98 単位を集約した.

分類の結果, 14 のサブ・カテゴリと，4のカテゴリ が抽出され（表 2)，抽出された 4 つのカテゴリをそれ ぞれ「1，具体的な表現で可視化された様式には，客観 性, 公平性, 利便性などの『利点』が多数存在する」(以 下，カテゴリ 1)，「2．客観性の不十分さと，使用する 際の不慣れや戸惑いなどの『課題』が存在する」（以下， カテゴリ2),「3. 様式改訂の勧めと『具体的な要改善 箇所』が存在する」(以下, カテゴリ 3),「4. 内省への 応用や，斬新な活用法は実習教育に新たな『可能性』を もたらす」（以下，カテゴリ4）と命名した。

まず，「カテゴリ1」は，43 単位の記録単位と 7 つの サブ・カテゴリから構成され，ルーブリック導入の趣旨 でもある，目標と各種基準を具体的な表現で可視化する ことによる実習成績報告書の客観性, 公平性, 利便性な どを含む様式の利点を, 使用者である実習指導者が感じ たことを意味する.

次に，「カテゴリ2」は，34 単位の記録単位と $3 つ の$ サブ・カテゴリから構成され, 実際に実習指導者が学生 の実習成績評価にルーブリックを使用して感じた，戸惑 いや曖昧な点などの，ルーブリックに対する課題がまと めてある

「カテゴリ $3 」$ は, 12 単位の記録単位と 2 つサブ . カテゴリから構成され, 実習成績報告書の様式にルーブ リックを導入し，目標や基準などの表記を具体的な表現 で可視化した様式で運用したからこそ顕在化した「様 式」・基準内容」に関した, 使用者の感想からよみとけ る具体的な改善箇所と提案がまとめてある.

最後の,「カテゴリ4」は，9単位の記録単位と $2 つ$ のサブ・カテゴリから構成され, 実習指導者が実際の学 生指導に活用して, ルーブリック様式を振り返りへの応 用ができたことや，先験的な使用法を試みて感じたこと からよみとける, これからのルーブリックの可能性をま とめた。

各命名は, サブ・カテゴリの共通の内容から検討して 導き出し，第三者に協力を依頼して検証した Scott.W.A の式による一致率は，それぞれ $86.5 \% ， 86.4 \%$ となり， カテゴリの信頼性を確保していた。
IV. 考 察

近年, 実習教育の在り方の一つに, 養成校と実習施設 との連携強化が再重要視されるようになってきてい る 13). 本校では, 臨床実習ルーブリックの開発から導入 運用実践を踏まえた様式の検証と改定を行うにあたり， 開発者側である養成校と使用者側である実習指導者間に おいて，ルーブリックを用いた実習成績評価に対する意 識の共有と理解が重要であると考えた。今回の研究では, 実習成績評価の様式としてルーブリックを使用した実習 指導者の感想を要素として集約し, 結果として抽出され た課題やそれらに対する改善案として得られた知見から， 質的な手法を用いて分析を行い, 様式の改訂を行うにあ たっての妥当な根拠を得ることを目的としている.

まずカテゴリ 1 は，実習指導者の感じたルーブリック の「利点」をまとめたカテゴリとした、ルーブリックの 使用者である実習指導者は，学生の状態を明確な表現で 可視化することができ，実習成績評価様式としても使い やすく, 結果の公平性の高さも担保される様式であると 感じていることがわかった。その他にも成績評価の記入 時のみならず，実習教育を進める上でルーブリックを活 用して「学生の成長度の可視化が容易であったと感じ た」や，実習を通し「ルーブリックを指導ツールとして 活用することで学生と実習指導者間での相互理解が図れ た」などの, 形成的評価の意味を含んだ結果も得られた。 これらは，本校と実習施設間における協同したルーブ リックの運用から, 明確な表現で可視化した各基準が評 価の公平性や結果の客観性につながるという養成校が開 発時に留意した要点17)を, 実習指導者もルーブリック の「利点」として感じていることを明らかとした。この ことは, 養成校と実習指導者との実習成績評価に対する 意識や方向性に共通点が存在し, さらには, 双方のコン センサスがとれているとも捉えることが可能で, 結果と してルーブリックの運用は養成校と実習指導者間におけ る相互理解を深めることにつながったと解釈できる。

また，使用者である実習指導者は，以前の 5 段階評価 の様式と比較して，ルーブリックは容易に使用でき，か つ客観的な評価結果となるような，使いやすく，かつ実 用的な様式となったことに「利点」を感じていることな どからも, 様式の「利点」を整理したことは, 今後のルー ブリック運用継続への前向きな根拠の一つとなった。

次にカテゴリ 2 は, カテゴリ 1 の利点とは対照的な, ルーブリックの「課題」をまとめた。開発段階当初より, 実習指導者を中心とした多くの第三者を交え，学内外で 1 年を超えて検討を繰り返したにもかかわらず，会議に 参加した実習指導者の回答結果には, 未だ記入のしづら さや評価基準の曖昧さ, 判断の際の迷いなどの指摘が存 在した。サブ・カテゴリは，「見慣れない様式と新しい 記入方法は使用者に不便や戸惑いを生じさせる」や「定 
表 2 ルーブリックの使用者となる実習指導者は, 新たに導入した様式を使用してどう感じたか

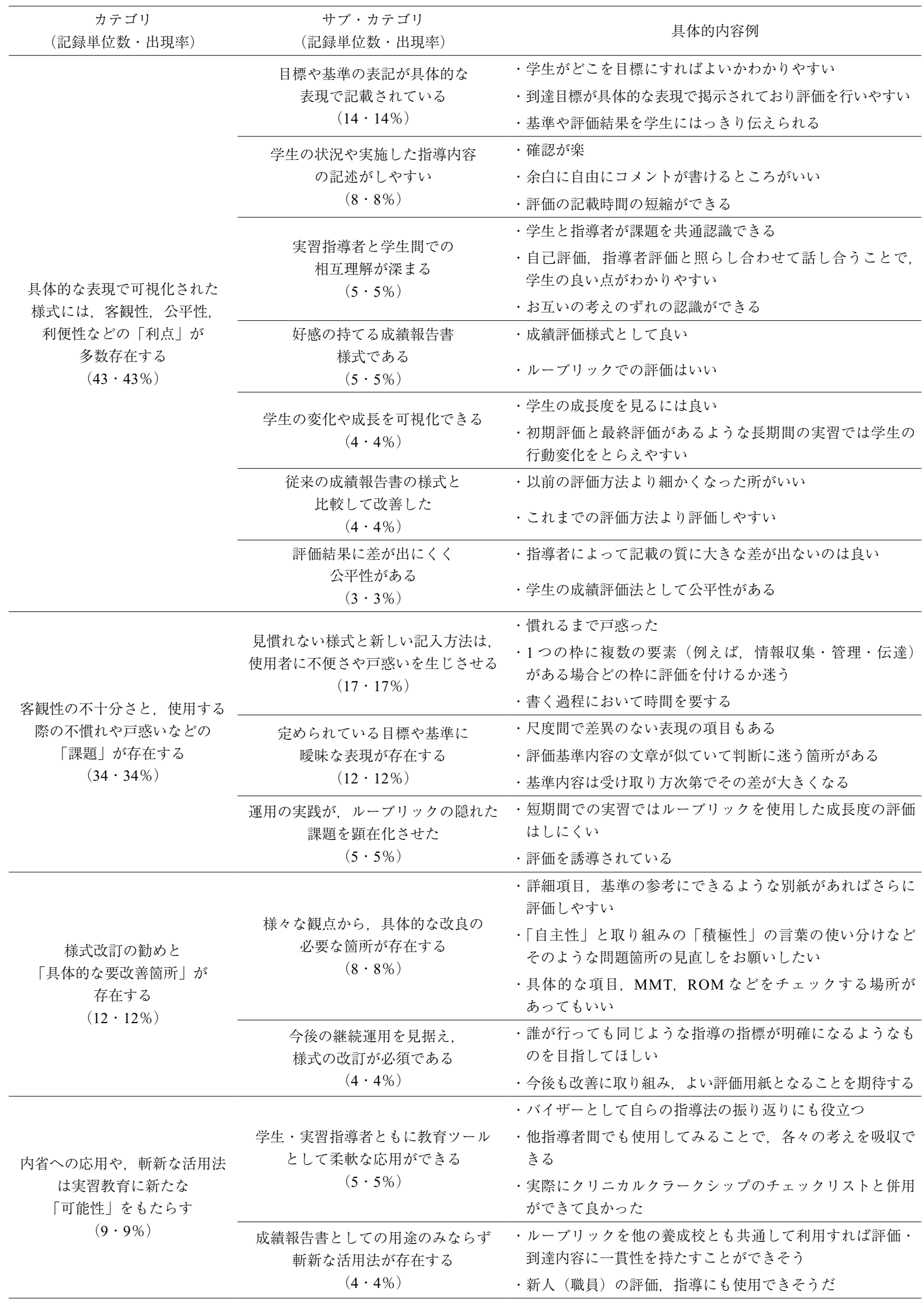


められている目標や基準には表現の不明瞭さや曖昧さが 存在する」などと, 各基準に定めた記述の意味内容を理 解しにくいといった内容が多く抽出された.

まず，実習指導者が様式に記入する際に感じる不慣れ や戸惑いは，評価基準と評価尺度が枠で囲まれた記述語 で全て構成されるルーブリックの見慣れない様式に加え, 指導者それぞれが自らの判断で 5 段階の中から到達度に 近い值を選択していた従来の様式から, 基準の詳細が具 体的に記述された様式に変更された点にあると考えられ る.これまでの, 各評価項目に対して定められた大まか な評価尺度の值を自らで判断し, 選定していた評価方法 が，ルーブリックを用いた評価方法では，はじめから評 価項目に対する評価尺度それぞれの基準が具体的に記述 して定められており，その判断に関わる加筆を実習指導 者自らも加えなければならないといった使用方法の異な りが，不慣れや戸惑いを感じさせた要因ではないだろ うか.

次に，表現の不明瞭さや曖昧さに関しては，開発した ルーブリックに一つの評価尺度の枠内に多数の要素を含 んだ記述で基準が作成されている箇所が存在した。また 到達度の判断目安は, 平均的な到達度 (4段階中 2 段階 目）を「継続指導すれば改善する」，最も低い到達度（4 段階中 1 段階目) を「継続指導しても変化がみられない か見込めない」という基準で作成した。しかし一部の評 価項目に, この解釈基準と異なる箇所が存在し, 実習指 導者に尺度基準の曖昧さを感じさせてしまったことが考 えられる。

これらより，使用の際の不便や戸惑い，表現の曖昧さ に対しては実習成績報告書の様式自体にルーブリックの 趣旨と記入方法の確認ができる注釈を加えることと，1 つの評価基準に, 可能な限り多くの要素を含んだ表現を 用いないこと, 評価尺度間の解釈と到達度を明確にでき る基準内容を再考する必要性があることがわかった，加 えて,「従来の実習成績報告書の評価の方法が異なる様 式であること」や，「実際に学生を担当して教育実践を 行う理学療法士と, 会議の参加者である実習施設の代表 者とでは，実習教育の担当が異なってしまう場合があ る」などの意見に対して，ルーブリック評価の趣旨や使 用方法を含んだ本校の実習教育評価の概要を, 会議参加 者のみではなく実習教育に携わる全ての理学療法士に理 解してもらえるような実習施設側に対する促しも必要で あることもわかった

さらに，改訂へ向けて着目したい興味深い知見が二つ 存在する。一つ目は, 学生の状態を客観的な表現で容易 に可視化できるというルーブリックの長所を活かし，今 回, 学生の中間評価と最終評価の結果ルーブリックに書 き込める工夫をして, 実習期間内における学生の成長を 「みえる化」ができる使用方法の推奨を行った。しかし， 最終学年時に履修する長期臨床実習の様式から開発を着
手したことも影響して，短い期間となる見学実習や検査 測定実習においては，短期間で学生の現状と成長度の可 視化まで評価することは困難だという指摘が得られた。 これらは短期間の実習で用いるルーブリックの様式の構 成や, 使用方法の変更などの再検討が必要なことを明ら かとした。

二つ目は, 開発者側はルーブリックに示した枠内の評 価基準に具体的な表現を用い，その可視化から，公平で 客観性の高い成績報告書をねらいとしたが，その具体的 な表現こそが成績評価の判断を誘導されているように感 じた実習指導者の意見が存在した，これらは，養成校の 定めた評価基準と実習指導者の考える評価の判断基準と の間になんらかの差異が存在することを表し, 評価基準 に対する養成校と実習指導者の認識を, 改めて別に検証 する必要があることがわかった。 したがって, 今後もこ れらの検討を継続することは，養成校と実習指導者がお 互いの考える目標や基準に対する認識のズレを明確にし て修正を繰り返すことができ，評価の内容的妥当性を高 めることにつながると考える. よって, 今後の指導者会 議においても，目標と基準に関する実習指導者との意見 交換を積極的に行い, 改訂の際は, 全ての評価項目や基 準内に使用している用語の定義と, 文章の意味内容を考 慮した用語の採用や使い分けなどを慎重に行う必要があ ることがわかった。

カテゴリ 3 は，これまでに述べたカテゴリ 1 の様式の 「利点」とカテゴリ 2 の様式の「課題」を踏まえ, 実習 指導者の提案する「具体的な要改善箇所」として抽出さ れたものがまとめられた。したがって，カテゴリ 3 の結 果に対しては，具体的な対策を考案することとした。ま ず，サブ・カテゴリの「様々な観点から具体的な改良の 必要な個所が存在する」からは, 具体的に「関節可動域 検査」や「筋力検査」などの特に精神運動領域に関連す る詳細記述ができるように, 評価項目数を増やす提案や 基準内容で使用されている用語の使い分けを見直してほ しいなどが存在した。評価項目数を増やしてほしいとい う提案に対しては, 評価の客観性を向上させることがで きるという一般化信頼性の先行研究 23) で, 評価者数や 評価項目数を充実化させることの有用性も立証されてい る。しかし, 本校の実習成績報告書の様式は, 日常の理 学療法業務の傍ら, 学生の実習教育を担わざるを得ない 多忙な実習指導者 8-24) の負担を増幅させないことを開 発時の目的の一つとしているため, 評価項目数は増やさ ずに A3 で 1 枚の様式のままで，ルーブリックを補填す る二つの別様式の作成を検討する対策を考案した。一つ 目は, 実習指導者がルーブリックを使用して基準の解釈 と学生の到達度判定を行う際に, 判断基準の確認に使用 できる詳細をまとめた基準一覧表を作成し，実習指導の 指針と各実習の要項が書かれた本校作成の臨床実習マ ニュアル（A4 サイズ 65 ページで構成）への添付を行う. 
基準一覧表は，一般的な臨床実習の教育目標と教育目 標 ${ }^{8)}$ を参考に臨床実習の目的と, その教育目標と教育 評価についてを述べ, 次いで, 本校の定める教育目標と ルーブリックを使用した教育評価の指針と方法，評価基 準の在り方と成績判定の方法を記す。内容詳細は, 15 項目あるそれぞれの評価項目の趣旨と到達目標を目指す ために必要な具体的指導や判断の際に, 確認ができる解 説を記す。また, 各評価尺度の判定をする際の迷いを最 小限にできるように，基準中に使用している用語の定義 を詳細に解説し，実習指導者が，実習期間中の学生指導 において, 目標や基準の詳細やその判断に関する疑問を 抱いた際などに, 適宜手に取って確認できるものを作成 する。

二つ目は，現在，実習中に経験した技術を適宜記録す ることを目的として，クリニカル・クラークシップにお いて使用されるチェックリスト25)を参考に，本校で独 自に作成して運用している理学療法技術経験チェックリ ストとルーブリックとを関連付けた新しい使用方法を再 検討することでこれらの提案に対する解決の目途を立 てた。

カテゴリ 4 には, 今後のルーブリックの「可能性」を まとめた。主に指導方法を選ばない汎用性の高い様式で あること, 評価様式の用途に加え, 指導者自身の振り返 りや新人教育への応用などの，ルーブリックの飛躍した 活用法を考案, 実践できてよかったという感想も存在し た、筆者らは, 先行研究においてルーブリックが実習教 育の質の可視化と教育水準の担保 - 成績報告書自体を学 習活動に活用できること，その汎用性の高さといった ルーブリックの 3 つの可能性に言及していた ${ }^{17)}$. カテ ゴリ 4 では，その 3 つの可能性と一致する実習指導者側 の知見が多数抽出され, 運用を通して, 臨床実習指導者 もルーブリックの様式で行う実習教育評価という新しい 取り組みに前向きで，かつ養成校も想定していなかった 実習指導者ならではの活用法を考案するまでに至ったと 解釈できる。ささらに，実習指導者は養成校が計画してい る様式の改訂に関しても積極的に捉えており, 将来的に は「ルーブリックを他の養成校同士で共用することで, 評価, 到達内容に一貫性を持たせることができる」とい う可能性までを指摘した先験的な内容も存在し, 改めて, 実習指導者側も実習教育に対する多角的な視点での連携 教育の必要性を感じていることが明らかとなった，

近年，全国の養成校においてもルーブリックの教育実 践への導入は積極的で，その報告や検討は積極的に行わ れている。しかし, 現状の理学療法士養成体系では, 冒 頭で述べた多様化した課題に加え, 大学, 専門学校など の養成機関種の違いや 3 年課程と 4 年課程の就業年数の 違い 8,26), 養成校ごとの実習期間の違い 8) などが存在し, 実習教育に関連する教育目標や評価基準, 評価方法や判 断基準の統一化を図ることは容易ではない.
多くの研究者は，かねてより養成校と実習指導者の共 同による教育的取り組みを推奨 12,13) している。重要な ことは目標や基準, 指導方法の統一化のみに重きをおく のではなく，各校が養成校と実習施設との関係性や条件 などを含んだ学校ならではの臨床実習の教育目標と基準, 指導方針を実習施設と協同して検討し合えるところにあ るのではないだろうか.

今回の臨床実習ルーブリックの研究を通した養成校と 実習指導者との教育連携は, 様式の改定のための有益な 知見を得ることができた。臨床実習における教育評価の 本質をとらえるためには, 改めて実習における成績評価 の価值を何においてルーブリックを開発し，運用するか を養成校と実習指導者とがあらゆる形で対話を通して振 り返る取り組みを継続することの重要性もわかった。ま た，これらの取り組みは，今後ルーブリックがそれぞれ の養成校独自による開発ながらも, 成績評価様式として 妥当な様式で, かつ客観性や実用性の高いものをつくり だせると考えている。

利益相反 本論文に関して開示すべき利益相反はない.

謝辞 本校のルーブリックの開発から実習指導, 成績報 告書の運用にわたり，ご協力下さっている実習指導者を 中心とする関係者の皆様方に感謝申し上げます，加えて これからルーブリックの導入を検討している養成校や, すでに何らかの教育評価様式にルーブリックを導入して 運用を実施している機関が，本研究による知見をその開 発や改良・改訂に取り組む際の一助として頂ければ幸い です。

\section{引用文献}

1) Stevens DD, Levi AJ : 大学教員のためのルーブリック評 価入門. 佐藤浩章 (監訳), 玉川大学出版部, 東京, 2014 , p2.

2) 松下佳代 : パフォーマンス評価一子どもの思考と表現を評 価する一。 日本標準, 東京, $2007, \mathrm{p} 10$.

3) 沖 裕貴 : 大学におけるルーブリック評価導入の実際一公 平で客観的かつ厳格な成績評価を目指して一，立命館高等 教育研究, 2014, 14: 71-90.

4) 玉利 誠, 宮崎至恵, 松崎秀隆・他 : 臨床実習に扔けるルー ブリックを用いた認知スキル指導の提案一クリニカル・クラー クシップの普及に向けて一，柳川リハビリテーション学院 · 福岡国際医療福祉学院紀要, 2015, 11: 18-23.

5) 四元祐子, 藤田賢太郎, 山下喬之: ルーブリックを用いたグルー プデイスカッション評価方法の検討。九州理学療法士・作業 療法士合同学会誌, 2016: 256-256.

6) 岡山加奈, 荻 あや子, 高林範子 - 他 : 既存の基礎看護学 実習評価表の課題とルーブリックを用いた評価表の提案. 岡山県立大学保健福祉学部紀要, 2014, 21: 9-16.

7) 文部科学省 : 大学設置基準第六章教育課程第二十五条の二. http://www.mext.go.jp/b_menu/shingi/chousa/koutou/053/ 
gijiroku/__icsFiles/afieldfile/2012/10/30/1325943_02_3_1. pdf（閲覧日2017年12月25日）.

8) 奈良 勲: 理学療法学教育論. 医歯薬出版, 東京, 2004, p151.

9) 宮本謙三, 宅間 豊, 井上佳和 : 臨床実習成績に対する妥 当性の認識と帰属要因の関連. 理学療法ジャーナル, 2002, 36: 883-887.

10) 中川法一, 青山 誠, 松葉好子 - 他：臨床教育の検証と新 たな方向性. 理学療法学, 2013, 40: 151-155.

11) 金山浩基, 座間味知彦, 名取悟美: 臨床実習成績とバイザー の総合判定の誤差について。リハビリテーション教育研究, 2017, 22: 214-215.

12) 楠本正順, 吉村 修, 濱田輝一・他：臨床実習指導者への 意識調査一理学理療法教育をどのように学んでいるか一. 第 48 回日本理学療法学術大会抄録, 2013, 40 (Supp1 2): 6 .

13) 吉村 修, 楠本正順, 濱田輝一・他：よりょい臨床実習指 導体制を目指した実態調査報告一指導で困ったことについ て一. 第50回日本理学療法学術大会抄録, 2015, 42 (Suppl 2): 758.

14) 久保田まり, 水間正澄 : 医療系臨床実習指導の重要性に関 する指導者側の認知. 医学教育, 2002, 33: 467-474.

15) 熊野貴紀, 谷 浩明: 全国理学療法士養成校の臨床実習 形態についてのアンケート調査. 理学療法科学, 2015, 30: 503-508.

16) 吉元洋一: 理学療法学教育の現状と課題. 理学療法学, 2015, 42: 651-652.

17) 山下喬之, 田口 光, 長津秀文・他 : ルーブリックで理学
療法士養成課程における臨床実習の成績評価が生まれかわ る. 理学療法科学, 2016, 31: 915-923.

18) 公益社団法人日本理学療法士協会 : 理学療法教育ガイド ライン, 第 1 版. 公益社団法人日本理学療法士協会, 東京, 2009.

19) 公益社団法人日本理学療法士協会 : 臨床実習教育の手引き, 第 5 版. 公益社団法人日本理学療法士協会, 東京, 2007 , pp15-20.

20) 山口陽弘：教育評価におけるルーブリック作成のためのい くつかのヒントの提案一パフォーマンス評価とポートフォリ 才評価に着目して一. 群馬大学教育学部紀要, 人文社会学編, 2013, 62: 157-168.

21）舟島なをみ：質的研究への挑戦, 第 2 版. 医学書院, 東京, 2007, pp41-79.

22) Scott WA: Reliability of content analysis. The case of nominal scale coding. Public Opin Q, 1955, 19: 312-315.

23) 山口陽弘, 清水真紀 : 英語学習者のための音読テストの信 頼性の検討一一般化可能性理論の適用と第二言語習得への 示唆一. 群馬大学教育学部紀要, 人文・社会科学編, 2009, 58: $155-168$.

24) 小林 賢：臨床に扔ける教育方法論一効果的な臨床実習の 進め方一. 理学療法学, 2014, 41: 203-206.

25) 中川法一:セラピスト教育のためのクリニカル・クラークシッ プのすすめ，第2版．三輪書店，東京，2007，p297.

26) 奈良 勲：理学療法の本質を問う。医学書院, 東京, 2002, pp95-102. 